\title{
Detection of Retinoic Acid Receptor Complex using Mass Spectrometry
}

\author{
Lin Zhang ${ }^{*, a}$ and Zeqing Song ${ }^{b}$ \\ ${ }^{a}$ College of Science, Guangdong Ocean University, Zhanjiang, 524088, PR China \\ ${ }^{b}$ Department of Internal Medicine, Guangdong Medical College, Zhanjiang, 524001, PR China
}

\begin{abstract}
O receptor de ácido retinóico é um fator de transcrição no núcleo celular que se liga ao ácido retinóico. A esfera de atuação do ligante do receptor gama do ácido retinóico humano (seu complexo com ácido retinóico e sua interação com a proteína I ácido retinóico ligante) foi estudada por espectroscopia de massa. O caminho do ácido retinóico a partir do doador até o receptor foi monitorado on-line. Não foi observado nenhum complexo terciário envolvendo ácido retinóico e as duas proteínas, indicando que o transporte do ácido retinóico a partir da proteína ligante I até seu receptor poder seguir um mecanismo de dois passos, que envolve a dissociação do ácido retinóico a partir de sua proteína em fase aquosa, seguida de associação ao aceptor.
\end{abstract}

Retinoic acid receptor is a transcription factor in the cell nucleus that binds retinoic acid. The ligand binding domain of human gamma retinoic acid receptor, its complex with retinoic acid and its interaction with retinoic acid binding protein I, were studied by means of mass spectrometric methods. The pathway of delivering retinoic acid from donor to acceptor was monitored online. No ternary complex involving retinoic acid and the two proteins was observed, indicating that the transport of retinoic acid from retinoic acid binding protein I to its receptor may follow a two step mechanism, which involves dissociation of retinoic acid from the donor protein into the aqueous phase, followed by association with the acceptor.

Keywords: retinoic acid receptor, retinoic acid binding protein, electrospray ionization mass spectrometry, noncovalent complex

\section{Introduction}

Retinoid family (retinol and its various metabolites) has significant effect on a variety of cellular processes, including embryogenesis, reproduction, vision and regulation of inflammation, growth and differentiation..$^{1-4}$ All-trans retinoic acid (ATRA) is the most active metabolite of retinoid. It is able to cross passively biological membranes and control cell functions by using specific intracellular retinoic acid (RA) receptors as signal transducers. The RA receptor family consists of retinoic acid receptor (RARs) and retinoic X receptor (RXRs). RARs, which are located in the nucleus function as ligandactivated transcription factors that modulate gene expression, bind to all-trans retinoic acid (ATRA) and 9cis retinoic acid (9-cis RA), whereas RXRs bind only to 9-cis RA. All the nuclear receptors, including RARs and RXRs, share common modular domains (A-F). ${ }^{5-7}$ Two

*e-mail: zhang166@gdou.edu.cn domains play a crucial role in nearly all aspect of their function: the central, highly conserved, DNA-binding domain (DBD) of approximate 66 amino acids and the Cterminal, structurally conserved, ligand binding domain (LBD) of approximate 250 amino acids. ${ }^{89}$ DBD domain contains two zinc finger modules, formatting two compacts finger-like structures that bind DNA. The LBD is a multifunctional domain that is responsible for ligand binding, receptor dimerization and interaction with other proteins such as coactivators. Molecular and genetic studies demonstrate that the actions of RA are closely tied to the functions of these receptors.

In addition to the RAR proteins acting as transcription factors in the nucleus, the uptake, transport and metabolism of retinoic acid is regulated by two carrier proteins called the cellular retinoic acid binding proteins (CRABP I and CRABP II). ${ }^{10}$ CRABPs modulate the effect of RA by regulating its intracellular level. CRABPs are believed to serve to solubilize, protect their ligand in aqueous cytosol and transport RA between different cellular compartments. 
It was previously proposed that CRABP I binds and retains RA in the cytoplasm ${ }^{11}$ and also facilitates its catabolism to polar metabolite, ${ }^{12}$ so that, it prevents RA from reaching the nucleus and interacting with nuclear receptors. However, it was recently demonstrated that both CRABP isoforms are present not only in cytosol but also in the nuclei of cells, ${ }^{13}$ implying that both proteins may serve to deliver retinoic acid to the transcription factor that is activated by it, namely the retinoic acid receptor. Studies of the processes of retinoic acid moves from CRABPs to RAR revealed that, transfer of RA from CRABP I to RAR involves dissociation of the ligand from the binding protein, followed by association with the receptor. ${ }^{14}$ However, although the genes for both CRABP isoforms from various species have been cloned and characterized, neither the exact functions of these proteins nor the distinct roles of the two isoforms are completely understood at present.

Up to now the main method that leads to characterize the weak noncovalent interactions between proteins and other molecules are X-ray crystallography and NMR. Electrospray ionization mass spectrometry (ESI-MS), which enables gentle ionization of large biomolecules, has been successfully used to study the noncovalent protein-ligand complexes. ${ }^{15-18}$ However, supramolecular mass spectrometry is still not a widely spread technique in the field of nuclear receptors. In this paper, we report an ESI-MS study of the LBD of human retinoic acid receptor gamma (hRAR- $\gamma$ LBD), the binding of ATRA with it and the transfer of ATRA from CRABP I to hRAR- $\gamma$ LBD. Our results suggest that mass spectrometry will be a powerful tool to study the mechanism of small hydrophobic ligands crossing biological membranes by using specific intracellular receptors as signal transducers.

\section{Experimental}

All-trans retinoic acid was purchased from Sigma. The ligand binding domain of human retinoic acid receptor gamma was purchased from Chemicon. Cellular retinoic binding protein I was expressed according to literature method. ${ }^{19} \mathrm{NH}_{4} \mathrm{CH}_{3} \mathrm{CO}_{2}$ and $\mathrm{CH}_{3} \mathrm{CO}_{2} \mathrm{H}$ were obtained from Fluka.

Lyophilized protein (both CRABP I and hRAR- $\gamma$ LBD) was cleaned in $20 \mathrm{mmol} \mathrm{L}^{-1}$ ammonium acetate using Centricon-10 microconcentrator (Amicon, Beverly, MA, USA). All-trans retinoic acid was dissolved in methanol at concentration of $3 \mathrm{mmol} \mathrm{L}{ }^{-1}$. Small aliquots of such solution were added to a protein solution to maintain the methanol level below $0.5 \%$. The concentration of CRABP I and hRAR- $\gamma$ LBD were measured from UV absorption at $280 \mathrm{~nm}$ using extinction coefficient $20,970 \mathrm{~mol}^{-1} \mathrm{~cm}^{-1}$ and $29,740 \mathrm{~mol}^{-1} \mathrm{~cm}^{-1}$, respectively. ${ }^{16,17}$ The concentration of ATRA was calculated using an extinction coefficient $45,000 \mathrm{~mol}^{-1} \mathrm{~cm}^{-1}$ at $350 \mathrm{~nm}^{18}$

All studies were performed using a JMS-700 MStation (JEOL, Tokyo, Japan) magnetic sector mass spectrometer. The protein solution was continuously injected into mass spectrometer at a typical flow-rate of $250 \mathrm{~mL} \mathrm{~h}^{-1}$ with an aluminum foil protected syringe (to avoid photoisomerization of retinoids in solution). Mass spectra were acquired by scanning the magnet at $5 \mathrm{~s} \mathrm{decade}^{-1}$ rate. Each recorded spectrum was an average of 30-50 scans.

\section{Results and Discussion}

\section{Verification of $h R A R-\gamma L B D$ with mass spectrometry}

Electrospray mass spectrometry analysis of peptides and proteins relies exclusively on soft ionization techniques that create intact gas-phase ions from biomolecules. The creation of intact molecular ions enables accurate measurement of molecular weight. Since this technique requires the use of volatile solvents such as ammonium acetate, hRAR- $\gamma$ LBD protein was firstly cleaned in $20 \mathrm{mmol} \mathrm{L}^{-1}$ ammonium acetate before injected into mass spectrometer for analysis. Two series of mass/charge $(\mathrm{m} / \mathrm{z})$ distributions are observed in Figure 1. Figure 1 (A) is the electrospray mass spectrum obtained for LBD under denaturing conditions (in 50\% methanol and 3\% acetic acid), which centered around the +25 charge state appear to accommodate charges more readily. Figure $1(\mathrm{~B})$ is the mass spectrum of LBD at neutral $\mathrm{pH}\left(10 \mathrm{mmol} \mathrm{L}^{-1}\right.$ ammonium acetate, $\mathrm{pH}$ adjust to 7 with $\mathrm{NH}_{4} \mathrm{OH}$ ), which exhibits a narrow distribution of charge states +10 to +12 . Formation of multiply charged ions is a characteristic of ESI-MS. The multiply charged ions are produced as the result of proton attachment to available basic sites on the protein molecules. The mass spectrum of protein shows a narrow distribution of low charge state under nondenaturing conditions, while denaturing conditions yield a broad distribution of high charge state. The low amount of charging under nondenaturing conditions is often explained by the conservation to some extent of the protein structure. The restriction of charging may be due to fewer exposed basic sites or more severe coulombic restraints in the protein. The mass spectrum provides molecular weight information with high accuracy and characterization of the multiply charged ions permited to confirming the molecular mass of LBD as 28271.8 Da, corresponding to amino acid sequence GSHMD (178)......E (423). 

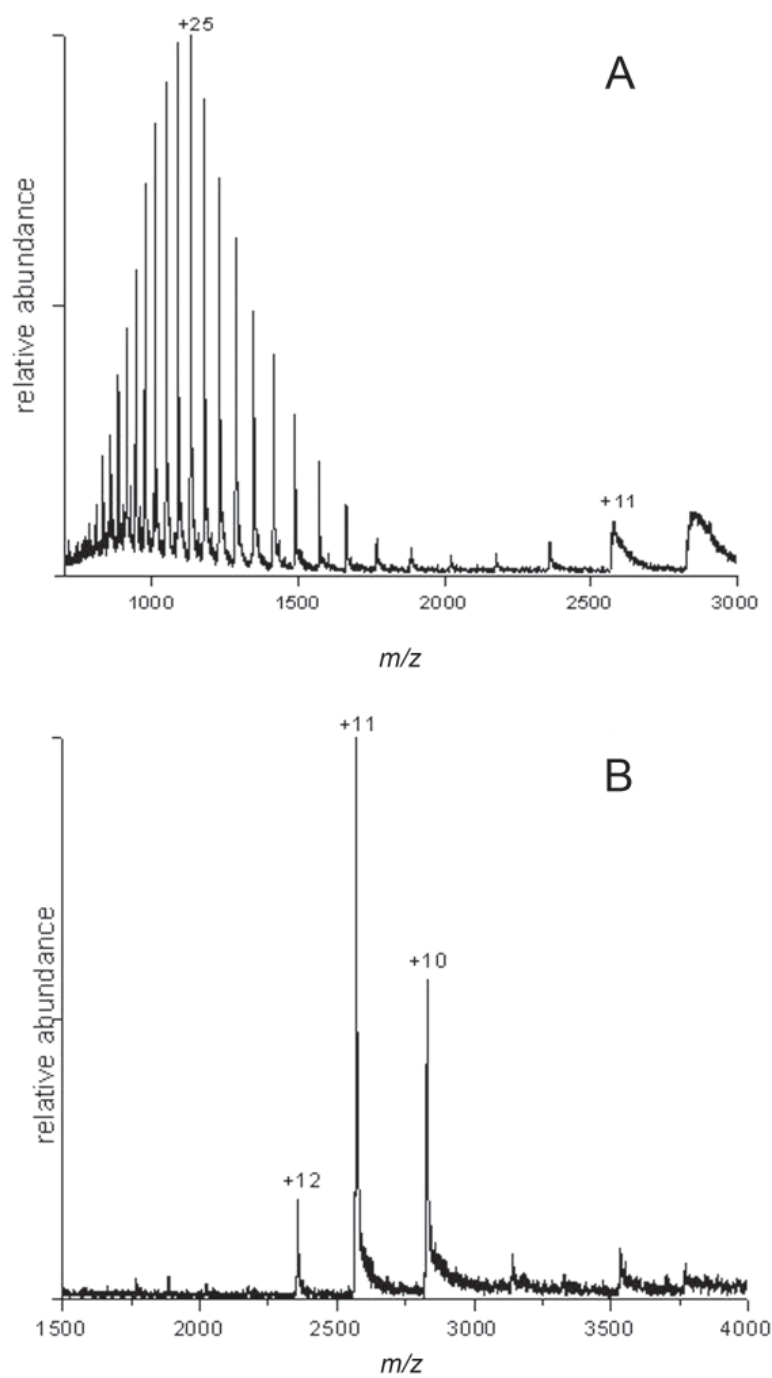

Figure 1. ESI mass spectrum of hRAR- $\gamma$ LBD (A) in $50 \%$ methanol and $3 \%$ acetic acid (B) in $10 \mathrm{mmol} \mathrm{L}^{-1}$ ammonium acetate, $\mathrm{pH} 7$.

\section{Characterization of ATRA binds to CRABP I and $h R A R-\gamma$ $L B D$}

The multiple biological actions of retinoids are mediated by two classes of proteins: retinoid receptors and retinoid binding proteins. Cellular retinoic acid binding proteins are carrier proteins involved in the intracellular transport and metabolism of all-trans retinoic acid. They bind all-trans retinoic acid with high affinity and modulate the effect of RA by regulating its intracellular level. The ability of electrospray ionization mass spectrometry to characterize noncovalent complexes has been widely illustrated..$^{20-22}$ In this work, ESI-MS is a method of choice for the study of noncovalent proteinligand interactions, since this technique allowed the unambiguous identification of the formation of proteinligand complexes. Figure 2 shows the ESI mass spectrum of a 1:1 mixture of CRABP-I and ATRA. Ions at $\mathrm{m} / \mathrm{z}$ 2252.9 and $1970.9 \mathrm{Da}$ were the $[\mathrm{M}+7 \mathrm{H}]^{7+}$ and $[\mathrm{M}+8 \mathrm{H}]^{8+}$ ions, respectively. They correspond to the mass of the CRABP I-ATRA complex, in agreement with the calculated value of 15760.8 Da. Detection of noncovalent protein-ligand complexes by ESI-MS requires relatively mild interface conditions to maintain integrity of the complexes. This is experimentally achieved by adjusting the ESI source conditions (orifice/ring lens voltage and desolvating plate/orifice temperature), which are critical parameters for the observation of noncovalent complexes. At high voltage and intermediate temperature, only ions from uncomplexed apo-CRABP I were observed (data not shown). Reducing voltage and intermediate temperature (orifice/ring lens voltage $0 / 60 \mathrm{~V}$ and desolvating plate/ orifice temperature $80 / 60{ }^{\circ} \mathrm{C}$ ), as shown in Figure 2, revealed the presence of holo-protein $(\sim 90 \%)$. In each of the relevant figures, the terms holo-protein and apo-protein have been used to denote the particular protein in complex with ATRA or uncomplexed, respectively.

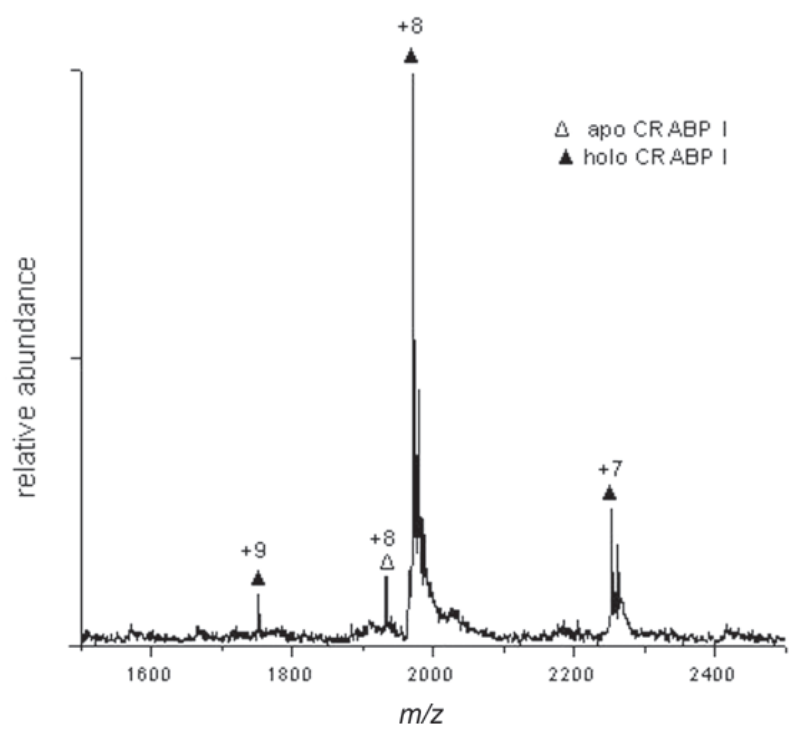

Figure 2. ESI mass spectrum of a 1:1 mixture of CRABP I and ATRA in $10 \mathrm{mmol} \mathrm{L}^{-1}$ ammonium acetate at $\mathrm{pH} 7$.

The C-terminal LBD domain of nuclear receptor is responsible for recognizing and binding the ligands as well as for controlling multiple receptor functions such as transactivation and transrepression. RA binds to the RA receptors, causing conformational changes that promote binding to specific cis-acting DNA sequences, which regulate transcription of certain target genes. Thus investigating RA binding to LBD is an important step in studying how retinoic acid exertes its effect. Mass spectrometry study of RA binding to LBD (RA:LBD = $1: 1$ ) is achieved at the same ESI source conditions as that 
for detecting CRABP I-ATRA complex (orifice/ring lens voltage $0 / 60 \mathrm{~V}$ and desolvating plate/orifice temperature $80 / 60{ }^{\circ} \mathrm{C}$ ). Figure 3 shows that $\sim 65 \%$ of the LBD protein was noncovalently bound to ATRA ligand under our experimental condition.

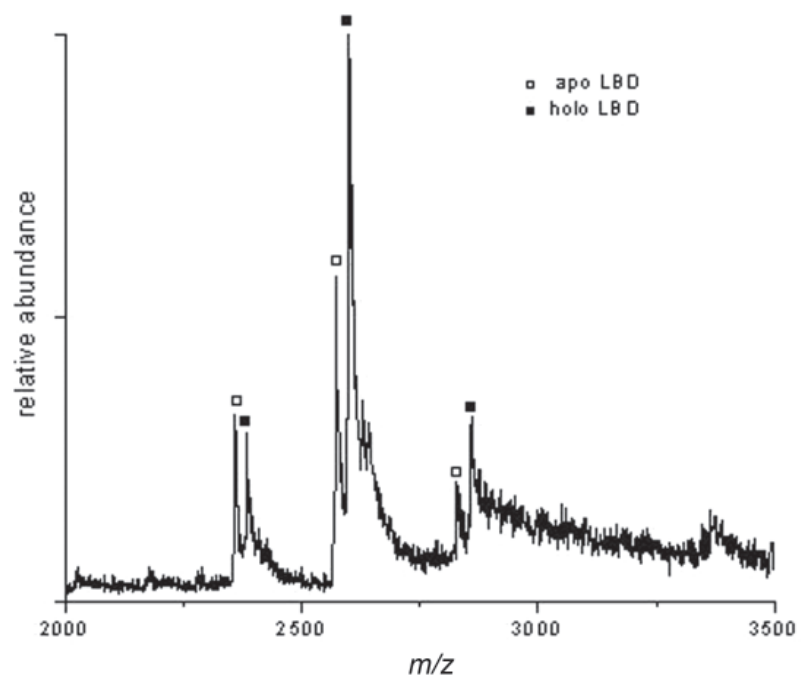

Figure 3. ESI mass spectrum of a 1:1 mixture of hRAR- $\gamma$ LBD and ATRA in $10 \mathrm{mmol} \mathrm{L}^{-1}$ ammonium acetate at $\mathrm{pH} 7$.

The knowledge of the three-dimensional structure of holoCRABPs is a good starting point for understanding their mechanism of action. CRABP contains two orthogonal $\beta$ sheets to form a solvent filled $\beta$-barrel. The ligand-binding pocket, which physiologically accommodates all-trans retinoic acid, is located inside the barrel. Retinoic acid is buried in the binding pocket with its carboxy head group, which interacts with two arginine residues and one tyrosine residue at the bottom of the pocket. The ligand is almost flat with the $\beta$-ionone ring showing a significant deviation from a cis conformation relative to the isoprene tail. The edge atoms of the $\beta$-ionone ring are accessible to solvent in a suitable orientation, that access to the entrance of the ligandbinding pocket of CRABP which appears to be restricted, ${ }^{23}$ implying that significant conformational changes are required to allow the ligand to move out of the site. That is why CRABP can act as cytoplasmic carriers for RA.

Crystallization studies of LBD domain ${ }^{24}$ have shown a common fold, formed by folding 12 conserved $\alpha$-helical regions named $\mathrm{H} 1$ to $\mathrm{H} 12$, with a conserved $\beta$-turn connecting $\mathrm{H} 5$ and $\mathrm{H} 6$, arranged in a three-layered antiparallel "sandwich". The center of this sandwich contains the ligand-binding pocket, lined mostly by hydrophobic and polar residues, some of which are critical for stabilizing the LBD structure. The binding of RA makes a stereospecific, high-affinity interaction with the pocket of the LBD, inducing a conformational change in the receptor. This conformational change results in changes in protein interaction and stimulates the recruitment of coactivators, leading to the activation of gene transcription.

As stated above, CRABP I delivering ATRA to LBD related to two conformational changes, the distortion of CRABP I to allow the ligand to move out of ligand-binding pocket and the distortion of the LBD is the ligand insert into the ligand-binding pocket. Thus, the stability of CRABP I-ATRA and LBD-ATRA complexes is an important element to decide the mechanism of transfer ATRA from CRABP I to RAR. Unfortunately, ESI-MS is only available to study noncovalent complexes in terms of existence and stoichiometry but fail in detecting the stability of noncovalent complexes. According to literature report, the affinity of CRABP for RA is in the same range (dissociation constant is about $\left.10^{-8} \mathrm{~mol} \mathrm{~L}^{-1}\right)$ as that of RAR. ${ }^{25}$

\section{Transfer of ATRA from CRABP I to hRAR- $\gamma$ LBD}

For the sake of investigating the potential protein interaction between CRABP I and hRAR- $\gamma$ LBD, we analyzed the mass spectrum of the two protein mixture (CRABP I: LBD = 1:1). In our study, no CRABP I-LBD complex was observed even mixing them for two days and then detecting under the mildest ESI source conditions. Figure 4 demonstrate that the transfer of RA is not correlated with direct interaction between these two proteins. Noncovalently bound protein and protein-ligand complexes can be sustained throughout the mass spectrometric analysis, thus providing the opportunity to monitor assembly mechanisms on-line and gain insights into assembly intermediates. An important question concerning the pathway of deliver of RA from donor to acceptor is whether or not their activity is mediated through a ligand binding channel. Recent studies report the assumption that transfer of RA from CRABP I to RAR involves dissociation of the ligand from the binding protein, followed by association with the receptor, ${ }^{14}$ which build upon the point of view that the reaction rate will be independent of the nature or the concentration of the acceptor. In order to get a insight to the possible pathway of CRABP I delivering RA to RAR, we first mixed equimolar concentrations of ATRA and CRABP I and after several minutes to allow ATRA binding completely, LBD was added (LBD:CRABP:RA = 1:1:1) and followed the mass spectrometry examination (Figure 5). There is no information of CRABP-RA-LBD detection and the addition of RA does not induce RAR:CRABP I complex formation in aqueous environment. These results are in good correspondence with the speculation that ligand will 
not move from the donor to the acceptor by "channeling", but initially, dissociate RA from donor protein into the aqueous phase, followed by association with the acceptor. In absence of LBD, mixed equimolar concentrations of ATRA and CRABP I result in about $90 \%$ holo CRABP I (Figure 2) but only $\sim 51 \%$ holo CRABP I exhibit in the presence of LBD (Figure 5), demonstrate that LBD may possess the equivalent ability of binding ATRA. However, it remains a puzzle to dissect the RA signaling pathways because the specificity of the actions of retinoids in different gene systems cannot be accounted for, by the actions of the donor or acceptor protein alone.

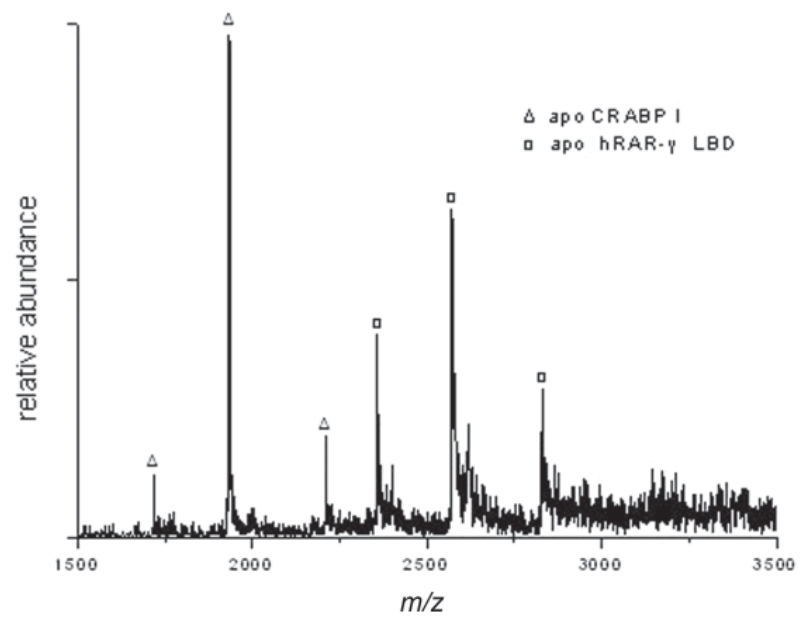

Figure 4. ESI mass spectrum of CRABP I mixture with hRAR- $\gamma$ LBD (1:1). ESI source conditions: orifice/ring lens voltage $0 / 60 \mathrm{~V}$ and desolvating plate/orifice temperature $80 / 60{ }^{\circ} \mathrm{C}$.

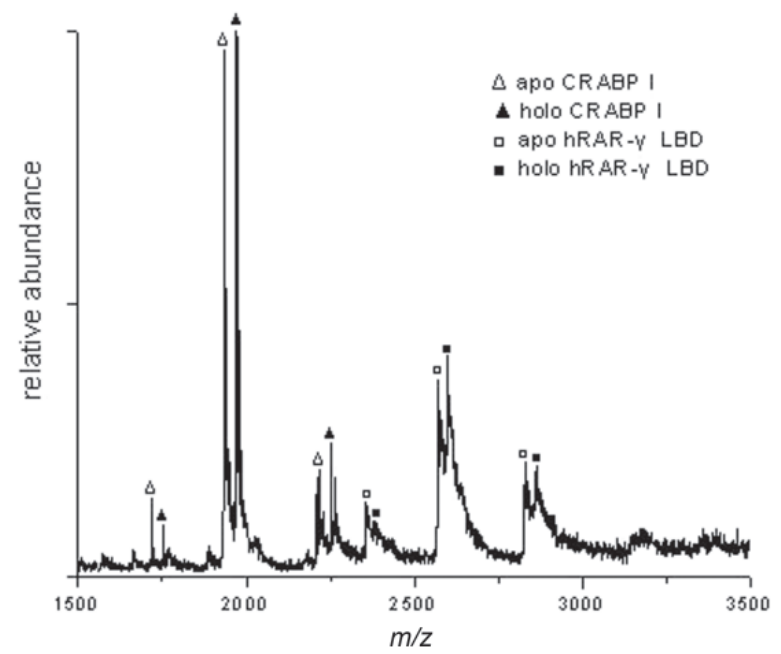

Figure 5. Transfer ATRA from CRABP I to hRAR- $\gamma$ LBD (CRABP:ATRA:LBD=1:1:1) ESI source conditions: orifice/ring lens voltage $0 / 60 \mathrm{~V}$ and desolvating plate/orifice temperature $80 / 60{ }^{\circ} \mathrm{C}$.

\section{Conclusions}

Mass spectrometry is an available tool to study bimolecular noncovalent complexes experimentally.
Employing electrospray ionization mass spectrometry technology, we have not detected the dimer of retinoic acid binding protein and retinoic acid receptor, disclosing that RA transform is not related to the interaction between donor and acceptor protein. From monitoring the pathway of delivering retinoic acid from CRABP I to hRAR- $\gamma$ LBD, we certify the postulation from experiment that RA transfer pathway involves initial dissociation of the ligand from the donor protein into the aqueous phase, followed by association with the acceptor protein. Our investigation demonstrates that mass spectrometry can be a powerfull tool to study ligand transport mechanism between cytoplasm and nucleus.

\section{Acknowledgment}

This work was supported by the National Natural Science Foundation of China (Grant 20271027).

\section{References}

1. Saari J. C. In Retinoids : The Biochemical and Molecular Basis of Vitamin A and Retinoid Action; Nau, H.; Blaner, W. S., eds.; Springer-Verlag: Berlin, 1999, vol. 139.

2. Becherel, P.A.; Mossalayi, M.D.; Goff, L.L.; Frances, C.; Chosidow, O.; Debre, P.; Arock, M.; Lancet 1994, 344, 1570.

3. Wagner, J.; Nephrol. Dial. Transplant. 2001, 16, 441.

4. T. Roos, T.C.; Jugert, F.K.; Merk, H.F.; Bickers, T.D.R.; Pharmacol Rev. 1998 50, 315.

5. Burns, L.L.; Dalessio, P.M.; Ropson, I.J.; Proteins 1998, 33, 107.

6. Pace, C.N.; Vajdos, F.; Fee, L.; Grimsley, G.; Gray, T.; Protein Sci. 1995, 4, 2411.

7. Roos, T.C.; Jugert, F.K.; Merk, H.F.; Bickers, T.D.R.; Pharmacol. Rev. 1976, 65, 71.

8. Benko, T.S.; Love, J.D.T.; Beládi, M.; Schwabe, J.W.T.; Nagy, L.; J. Biol. Chem. 2003, 278, 43797.

9. Pramanik, B.N.; Bartner, P.L.; Mirza, U.A.; Liu, Y.H.; Ganguly, A.K.; J. Mass Spectrom. 1998, 33, 911.

10. Takase, S.; Ong, D.E.; Chytil, F.; Arch. Biochem. Biophys. 1986, 247, 328 .

11. Boylan, J.F.; Gudas, L.J.; J. Cell Biol. 1991, 112, 965.

12. Fiorella, P.D.; Napoli, J.L.; J. Biol. Chem. 1991, 266, 16572.

13. Gaub, M-P.; Lutz, Y.; Ghyselinck, N.B.; Scheuer, I.; Pfister, V.; Chambon, P.; Rochette-Egly, C.; J. Histochem. Cytochem. 1998, 46, 1103 .

14. Dong, D.; Ruuska, S.E.; Levinthal, D.J.; Noy, N.; J. Biol. Chem. 1999, 274, 23695.

15. Dong, D.; Ruuska, S.E.; Levinthal, D.J.; Noy, N.; J. Biol. Chem. 1999, 274, 6294.

16. Loo, J.A.; Mass Spectrom. Rev. 1997, 16, 1. 
17. Bruce, J.E.; Smith, V.F.; Liu, C.; Randall, L.L.; Smith, R.D.; Protein Sci. 1998, 7, 1180.

18. Rostom, A.A.; Tame, J.R.H.; Ladbury, J.E.; Robinson, C.V.; J. Mol. Biol. 2000, 296, 269.

19. Liu, Z. P.; Riao, J.; Gierasch, L. M.; Biochemistry 1994, 33, 134.

20. Przybylski, M.; Glocker, M.O.; Angew Chem., Int. Ed. 1996, 35, 807.

21. Last, A.M.; Robinson, C.V.; Curr. Opin. Chem. Biol. 1999, 3, 557.
22. Tito, M.A.; Miller, J.; Walker, N.; Griffin, K.F.; Williamson, E.D.; Despeyroux-Hill, D.; Tiball, T. R.W.; Robinson, C.V.; Biophys. J. 2001, 81, 3503.

23. Kleywegt, G.J.; Bergfors, T.; Senn, H.; Motte, P.L.; Gsell, B.; Shudo, K.; Jones, T.A.; Structure 1994, 2, 1241.

24. Rogniaux, H.; Van Dorsselaer, A.; Barth, P.; Biellmann, J. F.; Barbanton, J.; van Zandt, M.; Chevrier, B.; Howard, E.; Mitschler, A.; Potier, N.; Urzhumtseva, L.; Moras, D.; Podjarny, A.; J. Am. Soc. Mass Spectrom. 1999, 10, 635.

25. Saurat, J. H.; Clin. Exp. Dermatol. 1988, 13, 359.

Received: April 24, 2006

Web Release Date: April 27, 2007 